DOI https://doi.org/10.18551/rjoas.2017-12.25

\title{
MESSAGES OF LOGO CHANGE ON INSTAGRAM'S BRAND IMAGE
}

\author{
Setephani \\ Magister Program of Management, University of Tarumanagara, Indonesia \\ E-mail: sweety.white.sw@gmail.com
}

\begin{abstract}
Logo is a symbol representing the image of a company, something that shows the existence of a company; while rebranding is an attempt performed by the company to change totally or renew an existing brand in order to become better, rebranding is frequently identical with a brand logo change. In 2016, Instagram logo changes from the iconic with the white-brown polaroid to a simpler design but with a strikingly visible color. Change in the company's logo can have a positive or negative impact on the company's brand image. The objective of this study is to determine what message obtained from the logo changes made by Instagram brand image. On the other hand, this research method uses qualitative methods and semiotic analysis of Charles Sanders Peirce with data collection techniques using nonstructured participatory observation techniques. The results show that the selection of colors and simple form used in the latest Instagram logo has strengthened the impression of spirit, dynamic, and transformation in a good direction on the brand image.
\end{abstract}

\section{KEY WORDS}

Communication, Instagram, logo, rebranding, semiotics.

In 2016, precisely on May 11, 2016, Instagram changes its iconic logo in the form of polaroid colored white-brown into a logo with a design that appears more colorful and visible with a blend of orange, white, orange, and pink, (Librianty, 2016). This logo changes according to Head of Design of Instagram, lan Spalter, is to present designs that are more in line with the application's aesthetic users and create something that represents the spirit and diversity of the stories that Instagram makes, (Librianty, 2016). It is not the first time that Instagram has changed its logo look. The first logo of Instagram is more similar to an original camera and is created by Kevin Systrom, (Librianty, 2016).

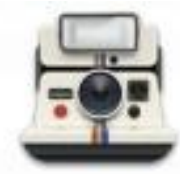

Figure 1 - The First Instagram Logo

When Instagram application would be launched in October 2010, this initial Instagram logo is constrained because it is similar to Instant Polaroid OneStep camera whose design has a trademark; therefore, Instagram logo is changed inspired by 1950 s camera, Bell \& Howell designed by Cole Rise, a professional designer and photographer, (Librianty, 2016).

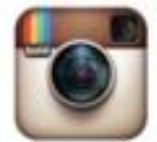

Figure 2 - Instagram-Cole Rise Logo

The second change of Instagram logo is done by Instagram to explicate Instagram evolution last 5 years, from Instagram which is just a photo sharing container filtered to become social media that is able to load video content and share message through direct message, (Librianty, 2016). Instagram is willing to make its product appear more modern and 
more relevant with the ages, so that its product is not just be a place to share video, but it is more than that, (Librianty, 2016). This latest logo is designed by a content creator and photographer from Sao Paulo, Brazil namely Paulo del Valle, (Librianty, 2016). A number of applications released by Instagram such as Boomerang, Layout, and Hyperlapse also experience a change in logo design. The third logo also contains the 'mandatory' color scheme, which is purple, orange, and pink, (Librianty, 2016).

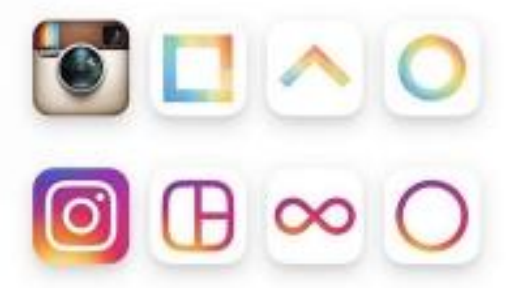

Figure 3 - Instagram Logo Change in 2016

Logo is a symbol representing the image of a company, something that shows the existence of a company, (Kelly, 2016). Logo is like to the face of a company, through the logo, there will be a trust towards the company and products produced by a company, (Kelly, 2016). Change in the logo in a company can affect people's perceptions of the image and the identity of a company, (Kelly, 2016). Change in the company's logo can have an impact both positive and negative, (Kelly, 2016). If it is positive, then the trust towards the company is increasing and if it is negative, it will make a decline of image or company image, (Kelly, 2016).

Research Problems. From the background aforementioned above, it can be known that the change in logo is not only about corporate identity, but it is also related to the brand image. Not a few companies that change the logo, but they get a poor response from consumers. Companies need customer feedback to see how well the logos are made as well as what consumers think when they see the logo. From the problem formulation above, then the problem that will be formulated is what is the meaning of Instagram logo changes to Instagram's company image?

In accordance with the problem of this study, then the objective of this study is to know what message of Instagram latest logo changes to company's image.

\section{METHODS OF RESEARCH}

In this study, the researcher uses the type of qualitative research. In qualitative analysis, the observed signs are not or cannot be measured systematically. Qualitative method does not rely on evidence based on mathematical logic, numerical principles, or statistical methods (Mulyana, 2001). In addition to qualitative analysis, the researcher also employs semiotic analysis method. Because by using semiotics method, the researcher can know the signs and symbols that exist on the latest Instagram logo (Sobur, 2006). The signs are analyzed and interpreted by using Charles Sanders Peirce semiotic method.

Data collection techniques used by the researcher is the technique of unstructured non-participatory observation. According to Meleong (2014), this non-participatory observation is the observation that only performs one function that is observing and not doing anything else that may affect the observed condition and does not disturb the structure of the unit of analysis. The researcher analyzes the Instagram logo by using the triangle meaning of Charles Sanders Peirce. The results of the overall analysis that the researcher do will be used to answer the main problem of research.

\section{LITERATURE REVIEW}

Theory of Semiotics. Terminologically, semiotics is a branch of science that examines signs and all things associated with signs, such as sign systems and processes that apply to 
signs, (Van Zoest, 1993). Semiotics is the study of a vast array of objects, events, and all cultures as signs, (Van Zoest, 1993). Sign, at that time, still means something that is pointed to the existence of something else. Semiotics is the science that learns about sign; the functioning of sign and production meaning of the signs convey information, so that it is communicative, (Van Zoest, 1993).

Based on its object, Peirce divides signs on icon, index, and symbol, (Van Zoest, 1993). Icon is the relations between sign and object or reference that have similarities. Index is a sign that directly refers to reality, (Van Zoest, 1993). Symbol is the sign that indicates the natural relationship between the marker and its signature, (Van Zoest, 1993). The interesting concept is expressed by Pierce related to the sign and interpretation of the sign associated with logic, (Tinarbuko, 2008). It is named as a triangle mark between ground (sign), denotatum (object), and interpretant. Ground is the basis of the sign, generally in the form of a word, (Tinarbuko, 2008). Denotatum is a sign of reality. Interpretant is an interpretation of the reality that is in the sign, (Tinarbuko, 2008). Where the three concepts are put into logic again into several parts of each interpretation of the terms of logic (Tinarbuko, 2008).

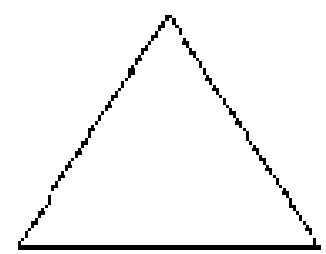

Figure 4 - Triangle of Charles Sanders Pierce Sign Object Interpretant (Source: Tinarbuko, 2008)

Based on interpretant, sign (representamen) is divided into rheme, dicent sign or dicisign and argument, (Sobur, 2006). Rheme is a sign that allows people to interpret by choice, (Sobur, 2006). For example, a blinking person may indicate that the person is just crying or suffering from an eye disease, or an eye entered by the insect, or just waking up, or wanting to slee,p (Sobur, 2006). Dicentsign or dicisign is a sign of reality. For example, if on a road there are frequent accidents, then on the side of the road traffic signs are posted stating that there are frequent accidents, (Sobur, 2006). Argument is a sign that directly gives a reason for something, (Sobur, 2006).

Based on these various classifications, Peirce divides sign into ten types, (Sobur, 2006):

- Qualisign, i.e. the quality to what extent of the mark has. Hard word indicates sign quality.

- InconicSinsign, i.e. a sign that shows similarities.

- Rhematic Indexical Sinsign, i.e. a sign based on direct experience which directly attracts attention because its presence is caused by something.

- Dicent Sinsign, i.e. a sign that provides information about something.

- Iconic Legisign, i.e. a sign that informs the norm or the law.

- Rematic Indexical Legisign, i.e. a sign that refers to a particular object.

- Dicent Indexical Legisign, i.e. a sign of meaningful information and pointing to the subject of information.

- Rhematic Symbol or Symbolic Rheme, i.e. a sign connected to its object through a general idea association.

- Dicent Symbol or Proposition (porposition), i.e. a sign that directly connects with objects through associations in the brain.

- Argument, i.e. a sign that is a person's judgment of something by reason.

Etymologically, the logo comes from the Greek word "Logos", meaning word, thought, speech, and reason (Kelly, 2016). According to Kelly (2016), logo is an image depicting the name of the brand, the logo acts as the face of the brand that makes the brand performance. Logo is a visual interpretation of the quality communicated from the brand (Kelly, 2016). According to (Adams, 2008), the performance relates to the business logo or product. An effective logo should have the following requirements, (Adams, 2008): 
- Unique and attractive to market target.

- Be able to describe the nature of the product business, or service. It can be interpreted in two ways: literal and abstract.

- Not easily obsolete or out of date due to time shift.

- Applicable in all potential communication contexts.

Color is a particular spectrum contained in a perfect white light, (Kusrianti, 2007). Initially, color was firstly discovered by Isaac Newton in 1660 by using the source of sunlight and prism as a light reflecting device. From the reflection, red, orange, yellow, green, blue, indigo and purple arisen which are later known as the spectrum arrangement in light, (Kusrianti, 2007). Theory and color recognition have been widely exposed by experts, including as follows (Kusrianti, 2007):

- Color Theory of Newton: The idea begins with a circle representing only three primary colors (red, blue, and green) derived from the additive color system.

The primary color is the color that guides everyone to use it. In the use, main color has two kinds; for graphics, the color used is a pigment consisting of blue (cyan), Red (magenta), and Yellow (yellow). In photographs and computer graphics, the primary color of light consists of red, green, and Blue (RGB). In Computer, the colors are cyan, magenta, and yellow are still added with color key (black), so that CMYK term is known.

The secondary color is a mixture of primary colors. Red and blue produce purple, red and yellow produce orange as well as yellow and blue produce green.

The tertiary color is a mixture of the secondary with the primary colors.

- Color Theory of Munsell: The importance of color role for human makes colors often used as aesthetic elements, as representations of nature, colors as communication, and colors as expression.

Color as an aesthetic element: the color plays itself as "color", which has a function in shaping a beauty.

Color as a representation of nature: the color is a depiction of the object nature in real, or in general, the color is able to describe the nature of objects in real.

Color as a communication tool or representation function: color places itself as part of a symbol. Color is a symbol a tradition or pattern.

Every color in the use of logo design has its own meaning that characterizes its company, (Harianto, 2015). The meaning of those colors is (Harianto, 2015):

- Black is generally associated with elements of strength, elegance, and formality. On the other hand, it can be attributed to evil, death, and mystery.

- White is a color that reflects purity, cleanliness, and virtue, generally regarded as a neutral color.

- Gray is a neutral color; it is generally conservative and formal, but it can also be modern. This color is frequently used in design firms, where formalities and professionalism are the keys.

- Brown is a color associated with dependence, reliability, fortitude, and also groundedness.

- Red is the color associated with fire, violence, war, love, passion, and spirit.

- Orange is a very vibrant color, representing change, movement, vitality and energetic.

- Yellow; this color is often associated with happiness, hope, excitement and it can be used in designs where a sense of eternity is to be highlighted.

- Blue, this color is often associated with sadness, tranquility, peace and responsibility. Dark blue reflects strength and reliability.

- Purple; this color is associated with creativity and imagination. Dark purple is traditionally associated with wealth and royalty, while bright purple is more romantic.

- Green is a color giving calming, fresh, and relaxing effect.

- Gold has the meaning of achievement, success, luxury, victory, and prosperity. It is just same as gold in physical form which becomes a precious commodity as well as a prestige in every country. 
- Tosca/turquoise has the meaning of emotional balance, stability, tranquility, and patience as well. Tosca color is believed to give the spirit when a person is mentally stressed or exhausted and is also seized with a sense of loneliness.

- Magenta is a blend of red and purple. The content of red color meaning spirit, strength and energy is restrained by the calm energy of violet color, so that it creates a balance. It has a philosophy of change or transformation. The change from unhappiness, frustration and anger to a better direction.

Shape is one of the basic elements in logo design. Certain shape or line can convey a universal meaning seen and provide an understanding of a purpose, (Kusrianti, 2007). There are three basic types of shape, namely geometric, natural, and abstract, (Kusrianti, 2007).

- Geometric Shape: structured and generally symmetrical. For instance rectangle, circle, triangle, seven-angle, eight-angle, and cone.

- Natural Shape: natural or organic shape can be found in nature or it can also be manmade. For example leaves or water droplets.

- Abstract Shape: a natural shape in a simpler or more stylish version. The shape of the abstract has a recognizable shape, but it is not real. For example a wheelchair shape symbol for access for people with disabilities.

Here are some meanings of the basic shapes (Kusrianti, 2007):

- Circle gives a dynamic, rotational, velocity, repetitive, uninterrupted, no beginning or ending, eternal, quality, dependability, perfect, and life impression.

- Box and rectangle show honesty and stability.

- Triangle represents dynamic pressure, action and aggression. Triangle can be used to convey developments, directions, and goals.

- Spiral is expression of creativity. It represents trust during change and maintains flexibility through transformation.

\section{CONCEPTUAL FRAMEWORK}

Rebranding is an attempt done by a company to completely change or renew an existing brand in order to become better by not ignoring the company's initial goal, i.e. profitoriented, (Febriansyah, 2013). Rebranding as a brand change is often identical with a brand's logo changes (Febriansyah, 2013). In other words, when doing rebranding, then what changed is the values in the brand itself (Febriansyah, 2013).

The logo change (rebranding) itself has the steps namely definition-develop-designdeliver, (Febriansyah, 2013). With the change of logo, it can be seen directly that form or logo design, font, color, and tagline are different from previous logo, (Febriansyah, 2013). According to Shimp (2003), whatever form of logo selected, then the logo must be seen (eyecatching) and unique or different; meaning that when consumers see the logo, then the consumer's memory will be directly addressed to the brand and not to other things that may be similar or identical to the brand which is visualized in the logo. If the logo is similar to the competitor's logo, then it will cause problems, (Shimp, 2003). In which in this case, the consumer would be more likely to brand competitors or even competitors will provide accusations of plagiarism, (Shimp, 2003).

According to Kotler (2005), image is a set of beliefs, ideas, and impressions owned by a person against an object. Image is a set of ideas and impressions used by someone about an object (Sulaksana, 2003). Understanding the image itself is recognized as abstract or intangible, but its form can be felt from the results of good or bad assessment (Sulaksana, 2003). It is such as acceptance and response both positive and negative (Sulaksana, 2003).

\section{DISCUSSION OF RESULTS}

The form used in the latest Instagram logo is a simplified version of the camera form, so there are only 2 blunt-edged bridges (curved lines) and one circle in the middle. 
Table 1 - The colors used in the Instagram logo

\begin{tabular}{|l|l|}
\hline Color & Meaning \\
\hline & $\begin{array}{r}\text { The purple color in this logo reflects Instagram supporting its users to be more creative in } \\
\text { every photo upload (Harianto, 2015). }\end{array}$ \\
\hline & $\begin{array}{r}\text { The magenta color has a philosophy of change or transformation (Harianto, 2015). } \\
\text { This orange color represents the Instagram company that continues to keep excited and } \\
\text { following the changes that occur (Harianto, 2015). }\end{array}$ \\
\hline
\end{tabular}

The box form used by Instagram in its latest logo would give the impression that Instagram company is a stable company, and the company symbolizes its dynamism by giving a curved line at the ends of the box, the shape of the circle that is in the middle of the box symbolizes the company which is not only stable, but it is also reliable, (Kusrianti, 2007).

\section{CONCLUSION}

In general, this present study aims to analyze and to describe the meaning of the signs contained in the Instagram logo. The signs are analyzed and interpreted by using Charles Sanders Peirce semiotic method, and based on the results of the research which have been described in the discussion, it can be concluded as follows:

Signs in the Instagram logo, the shape, and the color are in accordance with the brand image of Instagram company attempted to be represented through the logo. The use of magenta color on the Instagram logo represents Instagram transformation into a better application in sharing photos and videos. The three main colors in the latest Instagram logo are very representative regarding to Instagram's willingness to transform, excitement, following the latest trends and increasingly becoming a place for users to be more creative. On the other hand, shapes of of box and circle reflect Instagram as a stable, dynamic, and reliable company.

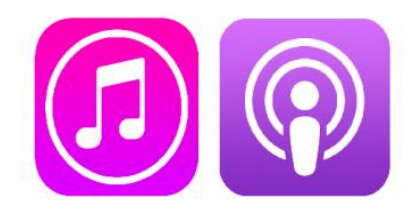

Figure 5 - iTunes \& Podcast Logo

Critique: The too-simple Instagram's latest logo makes it not looks special compared to the previous logo. The colors used in the latest Instagram logo at a glance look similar to the logo of iTunes and Podcast, so that when users search for this application on their smartphone screen, then Instagram logo does not stand out.

\section{REFERENCES}

1. Shimp, T.A. (2003). Periklanan dan Promosi, Erlangga, Jakarta

2. Adams, S. (2008). Masters Of Design Logos \& Identity. U.S.A: Rockport Publisher, Inc.

3. Febriansyah. (2013). Pengaruh Perubahan Logo (Rebranding) Terhadap Citra Merek Pada PT Telkom Tbk di Bandar Lampung. JMA Vol 18 No2. 
4. Harianto, H.C. (2015). Pentingnya Desain dalam Penggunaan Warna Sebagai Arti Dari Logo Perusahaan. http://www.isi-dps.ac.id/artikel/pentingnya-desain-dalam-penggunaanwarna-sebagai-arti-dari-logo-perusahaan/

5. Kelly, M. (2016). Analysing the complex relationship between logo and brand. Place Branding and Public Diplomacy, Place Branding and Public Diplomacy, doi:10.1057/pb.2016.3

6. Kotler, P. (2005). Dasar-dasar Pemasaran .Jilid 2, Jakarta.Indeks Media Gramedia.

7. Kusrianti, A. (2007). Pengantar Desain Komunikasi Visual. Bandung: Penerbit Andi.

8. Librianty, A. (2016) Kisah Inspiratif Perjalanan Logo Instagram. http://tekno.liputan6.com/read/2504962/kisah-inspiratif-perjalanan-logo-instagram

9. Meleong, L.J. (2004). Metode Penelitian Kualitatif. Bandung: Remaja Rosdakarya.

10. Mulyana, D. (2001). Ilmu Komunikasi Suatu Pengantar. Bandung: Remaja Rosdakarya.

11. Sobur, A. (2006). Semiotika Komunikasi. Bandung : Rosdakarya.

12. Tinarbuko, Sumbo (2008). Semiotika Komunikasi Visual. Yogyakarta : Jalasutra

13. Van Zoest, A. (1993) Semiotika: Tentang Tanda, Cara Kerjanya dan Apa yang kita Lakukan Dengannya. Jakarta: Yayasan Sumber Agung. 